\title{
CIVILIZATIONAL CHOICE OF A STATE AND PROBLEMS OF CONSTITUTIONAL REFORM IN UKRAINE
}

\author{
Tertyshnyk V. M., Yarmysh O. N.
}

\section{INTRODUCTION}

Statement of the problem. The idea of the distribution of power in the legislative, Executive and judiciary, as one of the modern principles of the legal State, together with the system of checks, balances and limits the authority of the Hetman, to prevent corruption, were quite wisely implemented yet in the Constitution of Pylyp Orlyk 1710 a year. But the problem of harmonization and improvement of the constitutional bases of her organization is not completed and the date.

The urgency of the problem is caused by new turns of the constitutional reform, part of the conceptual provisions of which unveiled in the new bill for amendments to the current Constitution.

Analysis of recent research and publications which discuss this problem shows that the problem of formation and organization of the activities of the legislature and harmonization of legislative process in the spotlight as politicians and scientists ${ }^{1}$. But the existing publication does not exhaust the

\footnotetext{
${ }^{1}$ Головатий С. Верховенство права. У 3-х книгах. Книга 2. Верховенство права: від доктрини до прецеденту. Київ: Видавництво “Фенікс", 2006. 1286 с. ; Коваль А.А. Забезпечення прав людини при провадженні негласних слідчих (розшукових) дій : монографія. Миколаїв: Вид-во ЧНУ ім. Петра Могили, 2019. 264 с. ; Козюбра М. Судова правотворчість: аномалія чи іманентна властивість правосуддя. Право України. 2016. № 10. С. 38-48; Колодій А. М., Олійник А. Ю. Права, свободи та обов'язки людини $і$ громадянина в Украӥні: підруч. Київ: Правова єдність, 2008. 350 с.; Коломоєць Т.О., Колпаков В. К. Науково-практичний коментар Закону Украӥни "Про запобігання корупиії”. Київ: Видавничий дім “Гельветика”. 2019. 588 с.; Корнієнко М.В., Тертишник В.М. Принципи права в розв'язанні юридичних колізій. Міжнародний науковий журнал “Верховенство права”. 2017. № 2. С. 10-16; Костенко О.М. Концепція прав людини: сучасний стан i перспективи розвитку. Бюлетень Міністерства юстиції України. 2011. № 11 С. 5-11; Мироненко П.В. Форма правління: політичні трансформації на зломі століть: монографія. К.: Академія, 2014. 220 с. ; Михайленко В.В. Співвіднотення засад верховенства права $і$ законності у кримінальному процесу Украӥни. Прикарпатський юридичний вісник. Івано-Франківськ, 2017. № 6 (21). Том 2. С. 158-163; Наливайко Л.Р. Захист прав і свобод в світлі положень Конституиії України та конвенції про захист прав людини і основних свобод. Держава і право. Юридичні і політичні науки. 2003. Спецвипуск. С. 343-345; Оніщенко Н.М. Принщип верховенства права та верховенства закону: взаємовиключення чи взаємозумовленість? Проблеми правознавства та правоохоронної діяльності. № 3. 2010. С. 3-7; Орловська Н.А. Справедливість $і$ верховенство права: актуальні питання кримінально-правової інтерпретаиії. Науковий вісник Херсонського
} 
whole complex problem, but rather to form a fundamental basis for subsequent research.

The aim of this work is to identify ways of harmonizing power and the constitutional process.

Our State has made a faithful civilizational choice and today is difficult, but keeps the course on the implementation of the principle of the rule of law. This complex and multi-faceted process must tap as a legal "person-the State and the Organization of the authorities. Many problems of organization of power Ukraine received in succession for another moment of receiving its independence, but through a different. Reboot the individual institutions.

In the structure of the legislature, it is advisable to foresee two chambers: the upper house - the Sejm, the lower House, is the "Vice" (people's Assembly). For constructive updates, the legislature should set the general constitutional rule - a citizen can be a member of the Parliament of not more than two consecutive terms. For selected has who submitted a declaration of their profit and your wealth in General, and confirmed that most of his

державного університету. Сер. : Юридичні науки. 2014. Вип. 6-1. Т. 3. С. 158-163; Петришин О. Верховенство права в системі правового регулювання суспільних відносин. Право України. 2010. № 3. С. 27-29; Подорожна Т. С. Правовий порядок: теоретикометодологічні засади конституиіоналізації: монографія. Київ: Юрінком Інтер, 2016536 с.; Принцип верховенства права: проблеми теорії та практики: Монографія: У 2-х кн. / За заг. ред. Ю.С. Шемшученка. К.: Юридична думка, 2008. Кн.1. Верховенство права як принцип правової системи: проблеми теорії. 344 с.; Сачко О.В. Концептуальна модель юридичного визначення принциипу верховенства права. Актуальні проблеми вітчизняної юриспруденції. 2018. № 6. Т. 1. С. 166-170; Ставнійчук М. Окремі проблеми новітнього конституиійного прочесу у світлі висновків Європейської комісіі “За демократію через право” (Венеціанська комісія). Право України. 2012. № 8. С. 146-153; Тертишник В.М. Вid тоталітарності до правовладдя: доктринальні аспекти державотворення. Право.иа. 2017. № 2. С. 5-11; Тертишник В.М. Правнича допомога та захист у кримінальному прочесі: Підручник / За заг. ред. д.ю.н., академіка НАН України Ю. С. Шемшученко. Київ: Алерта, 2018. 480 с. ; Тертишник В.М., Корнієнко М.В. White-Collar Crime в "модних піджаках”. Європейські перспективи. 2018. № 3. С. 55-54; Фулей Т.І. Застосування практики Європейського суду з прав людини при здійсненні правосуддя: Науковометодичний посібник для суддів. - 2-ге вид. випр., допов. К., 2015. 208 с.; Хавронюк М.І. Коментар законодавства Украӥни про права та свободи людини і громадянина. Київ: Парламент. 1999. 544 с. ; Цибуляк-Кустевич А.С. Сучасні виклики та актуальні проблеми судової реформи в Україні. Право України. 2018. № 11. С. 214-230; Ченцов В.В., Тертишник В.М. Реабілітація жертв незаконних кримінальних переслідувань, політичних penресій та зловживань владою. Підручник для слухачів магістратури. Київ: Алерта, 2016. 324 с. ; Шемшученко Ю.С., Скрипнюк О.В. Методологічні проблеми взаємодії держави $i$ громадянського суспільства в сучасній Україні. Правова держава. 2017. Вип. 28. С. 3-12; Шилінгов В. С. Верховенство права - основоположний принции правової системи демократичного суспільства. Часопис київського університету права. 2009/2. URL: www.kul.kiev.ua/images/chasopus ; Щербанюк O.В. Народна правотворча ініціатива як перспективний інститут прямої демократії в Україні. Порівняльно-аналітичне право. 2013. № 3-2. C. 97-100. 
property on the territory of Ukraine. Regulations of the legislature should be simpler and allow promptly take crucial laws.

Explanation of the basic material of the study.

\section{Institutional aspects of implementing the ideas of the legal state}

Having inherited the legal system built up on the ideology of totalitarianism, the people of Ukraine chose the main path of their development, with the aim of building a democratic, social legal state and consolidating these concepts in the main law of the state.

The fundamental principles of law that need more attention are the principles of separation of powers, rule of law and the responsibility of the state to the individual.

The executive branch of power in Ukraine was a "two-headed", divided into two parallel functioning and often duplicated one another system: the President with the President's Staff and the Prime Minister with the entire apparatus of the Cabinet of Ministers and ministers. The Cabinet of Ministers as a collective body has shown its ineffectiveness when it is necessary to make decisions quickly and bear personal responsibility for them (curtains that contain collective irresponsibility should be sent to the landfill of history). If we turn our attention to the US Constitution, it's easy to see another, simple and effective system of organization of executive power, headed by, of course, the President. It is considered appropriate in the process of constitutional reform in Ukraine to radically simplify the organization of executive power, through the subordination of all ministers directly to the President (by canceling the post of Prime Minister), and the Cabinet of Ministers to unite with the apparatus of the President, significantly reducing the staff of officials.

An important problem of the present constitutional process is the improvement of the activities of local self-government bodies. According to the proposals on changes to the wording of Article 118 of the Constitution of Ukraine, proposed by the draft law "On amendments to the Constitution of Ukraine concerning the decentralization of power", the executive power in the districts and regions is exercised by the prefects appointed by the President of Ukraine. Prefects should be replaced by heads of local state administrations, including so-called governors. The Prefect becomes not so much a "governor" as it will fulfill the functions of prosecutor supervision over observance of laws by local authorities. But will the prefect always be able to achieve legitimacy on the ground, and often to overcome the opposition of local officials, being outside the law enforcement system? Under the requirements of the law prefect can become a kind of "Don Quixote". It will be difficult for 
him to put the system in executive power in place for such an "asymmetry" of his competence. This is a problem of power imbalance.

Having inherited the legal system, based on the ideology of totalitarianism and collateral methods of command-administrative jurisdiction, today it is important to this organization, which would become a model of efficient management. Need to solve the problem of the Division of power and business, eliminate corruption schemes of privatization, stopping inflationary processes.

The financial and banking crisis can be largely overcome, if most wealthy people most of their foreign currency savings were placed in banks of Ukraine, rather than export them in the offshore area. The necessary guarantees of such deposits, the new guarantee of investment activity. It could be at the legislative level to consolidate the rule of the inviolability of property on deposits deposited at the National Bank of Ukraine, the prohibition of the imposition on them of arrest and seizure, except charges in crimes against humanity and the financing terrorism. However, should ban be appointed to legislative bodies and bodies of local self-government, or hold positions in the executive authorities individuals who most half his fortune stored in foreign banks. The Executive must be formed not from politicians and leaders from the business, and with professionals and people that meet the requirements of integrity, the society presents to the judges. Business should be deprived of the opportunity to use the power.

The legislative body of Ukraine is the Verkhovna Rada, which should work more qualitatively and not create a situation of permanent reforms. The name of our legislative body should not emphasize its "supremacy", it would be more appropriate for the Ukrainian parliament to name "Parliament", in the structure of which there are two chambers: the upper chamber - the "Sejm", and the lower chamber - "Veche" (people's assemblies). A constructive update of the legislature should establish a general constitutional rule: a citizen may be a member of the parliament for no more than two consecutive terms. Only those who filed a declaration of their profits and their wealth in general should be allowed to be enlisted, and confirmed that most of his property is in Ukraine, is invested in Ukraine.

Elections to parliament should take place in such a way that the composition of the parliament does not change at once in full, and is renewed every two years by one third (deterrence from radical changes and upheavals), therefore, it is more appropriate to have a bicameral legislative body.

The judiciary should be as independent of the others. The current system of appointment and dismissal of judges does not ensure such an approach. This applies both to courts of general jurisdiction and the Constitutional Court of Ukraine. It would be desirable to return to the election of judges by the people. 
The renaissance of the jury should take place in the light of its classical model, which was chosen by England, the United States, Russia and other countries, which showed their merits during the 1864 Statute of Criminal Procedure. In a jury trial, the question of guilty (this issue is decided by the jury in the verdict) should be separated from the issue of punishment (this issue is decided by the judge in the sentence). This judicial power is divided into two mutually controlling parts, which limits the possibilities of abuse, corruption and pressure on the judiciary, strengthens the principle of impartiality and independence of the court and reduces the risk of court errors.

At the same time, the work of peace judges should be restored. Peace judges are a democratically elected judicial body, whose simplicity has provided procedural economy, and its work should deepen the implementation of the idea of humanism in the judiciary.

The state is responsible to the people for their activities, it is so defined in Article 3 of the Constitution of Ukraine. An important form of the implementation of this idea was the Law of Ukraine "On the Procedure for Compensation of Damage Inflicted on the Citizen by Unlawful Acts of Inquiry, Pre-trial Investigation, Prosecutor's Office and Court". Meanwhile, a separate settlement of the procedure for compensation for damage caused to a citizen by unlawful actions of officials of executive authorities and local self-government is needed. Based on the above norms of the Constitution of Ukraine, it is necessary to develop and adopt a systemic legislative act - the Code of Rehabilitation of victims of illegal actions or inaction of the authorities.

At the same time, with the emergence of Ukraine as an independent state, with an increasing separation from the totalitarian past, with the new winds of revolution of dignity, we must take care of the dignity of several lost generations of the past and of the prospect of future generations. Mykola Berdyaev rightly wrote: "The state does not exist to transform the earthly life into paradise, but to prevent it from becoming finally into hell".

One of the important problems is to ensure the inevitability of the responsibility of those who organized and carried out mass political repressions and terror against the Ukrainian population. It would seem appropriate to add section XX of the Criminal Code of Ukraine to article 448 "Political repressions and terror".

To ensure the human rights, it is expedient to introduce in Ukraine a separate National Human Rights Court, whose jurisdiction would include consideration of actions of a person against the organs of state power of Ukraine and their officials. In our opinion, the creation of such a judicial body can improve the implementation of the institution of State responsibility to a person, promote the strengthening of the rule of law in the activities of state authorities. 
The National Human Rights Court should be set up in Ukraine based on maximum independence of judges from the authorities. Consequently, the appointment of judges to positions of any branch of government should not be affected. Therefore, most likely, the election of judges will be justifiable by all national elections.

Along with the introduction of amendments and additions to the Constitution of Ukraine, a separate Law of Ukraine "On the National Court of Human Rights" should be adopted. In our opinion, the creation of such a judicial body can improve the implementation of the institution of State responsibility to a person, promote the strengthening of the rule of law in the activities of state authorities.

It is necessary to preserve and multiply the realization of the fundamental principle of a state governed by the rule of law - when adopting new laws, it is not allowed to narrow the existing human rights and freedoms as a guarantee of non-return in a sad past.

The strategic goal of Ukraine is building a social legal State. If the goal is to develop social legal State then the strategy must include the formation of the principles of law, the creation of institutions of checks and balances against the retreat from the goal.

In the current legislation do not quite successfully implemented the principle of legal state-the principle of distribution of power into legislative, Executive and judicial, in order to provide reliable mechanisms of checks and balances against possible abuse, of stagnation, inconsistencies challenges of time.

To ensure human rights, it is advisable to establish in Ukraine, its single National Court of human rights, whose jurisdiction included as time consideration of actions of the person against the bodies of State power of Ukraine and their officials.

To ensure the independence of the Attorney General it is advisable to set the rule that appointment to the post will be appropriate to a constitutional majority, and release only in the application of the Institute of impeachment.

In the legislation of clean power, it is advisable to fix the rule that a government official, who filled out a declaration of their income and wealth that did not match his wages and other legitimate profit, must be released from any position of the ban to run in elective bodies.

Will and the land are the main components of the Ukrainian national idea, integral principles of a legal State, the most fundamental principles of Statebuilding.

In doctrine will highlight the following its structural or purely industry ideas-principles: the freedom to freely and with dignity to live and not be enslaved; personal integrity; freedom to do whatever is not prohibited by law; prohibition of coercion; privacy, right to free thinking; the right to the free creative activity 
The land and the will of these people on the basis of natural law. The Earth may not be the commodity because it is not created by the commodity producer and may not have a cost. Its like the freedom you can not to lose or sell. The Earth is a unique treasure of the whole society, which may not be the only means of organization of the land, but also a certain guarantor of sovereignty and the will of the people.

At this stage of nation-building it is advisable to develop a new version of the Constitution of Ukraine, which more clearly realize the principle of a legal State is the principle of the distribution of power, the more clearly legally determine the functions of State bodies, to simplify the Organization of the Executive branch. It is advisable to implement the idea of a bicameral Parliament, Executive authority is fully uploaded to the competence of the President of Ukraine, attach the prosecutors perform oversight functions ensuring the rule of law in the country, to expand the jurisdiction of the Commissioner of the Ukraine on human rights.

In the structure of the legislature, it is advisable to foresee two chambers: the upper house - the Sejm, the lower House, is the "Vice" (people's Assembly). For constructive updates, the legislature should set the general constitutional rule - a citizen can be a member of the Parliament of not more than two consecutive terms. For selected has who submitted a declaration of their profit and your wealth in General, and confirmed that most of his property on the territory of Ukraine. Regulations of the legislature should be simpler and allow promptly take crucial laws.

In the process of constitutional reform in Ukraine radically simplify the Organization of the Executive Branch is to subordinate all Ministers directly to the President (to fill the post of the Prime Minister) and the Cabinet of Ministers, combined with the apparatus of the President, significantly reducing State officials.

An important principle of the legal state is inadmissibility in the adoption of new laws narrowing the existing human rights and freedoms (article 22 of the Constitution of Ukraine). But the legislation does not provided reliable mechanisms of checks and balances against violations of this principle. We propose to establish criminal liability of legislative authorities for voting for laws that narrow the existing rights and freedoms of the person. A similar responsibility should also be established for executive officials and law enforcement agencies for the adoption of regulatory acts and narrowing the human rights and freedoms enshrined in the laws.

\section{Doctrinal aspects of ensuring the rule of law in the sphere of justice}

European standards of justice system generally accepted European Community reforming definitions, principles, guidelines, instructions, general 
regulations, legal positions and precedents set forth in separate conventions, resolutions, recommendations or other international legal acts, as well as in legal positions and precedent the decisions of the European Court of human rights, which are fixed standardized relationship between man and the State and its institutions in the field of Justice.

In providing equitable justice a significant role have the following fundamental principles of criminal proceedings as the rule of law and legal certainty, and formed on this basis of procedural form of criminal proceedings. Procedural form defines in detail the regulated law, mandatory, stable and protected legal regime of the State of proceedings in criminal matters, which aims to create a system of guarantees of truth, freedom and justice, to promote realization of the ideas of legal State in the sphere of Justice.

Procedural form must meet the requirements: feasibility (to provide fast, accurate and effective justice); simplicity (be free from unnecessary bureaucratic formalities); reliability (ensure the achievement of truth and justice); tolerance (to ensure respect for human rights and freedoms); capacity for self-purification, fix committed abuses and errors, clarity, morality and ethics. A simplified procedure of criminal justice, which achieved the necessary savings, is allowed provided the guarantees ensuring the protection of human rights and freedoms and fair justice.

According to paragraph 5 of article 364 of the Criminal Procedure Code of Ukraine "in the court debate the parties of the proceedings can use only evidence which was examined in court session". According to the requirements of part 4 of Art. 95 "the court can justify its findings only on the evidence which were said during the hearing". In part 3 art. 370 of the Criminal Procedure Code of Ukraine it is defined that "the decision, which is made by court on the basis of objectively clarified circumstances which are confirmed by the investigated proofs during trial and estimated by court according to article 94 of this Code. So, paragraph 2 of part 1 of article 468 of the Criminal Procedure Code of Ukraine, article 472 of the Criminal Procedure Code of Ukraine and part 2 of article 473 of the Criminal Procedure Code of Ukraine (regarding the agreement between the prosecutor and the suspect or accused on the recognition of culpability) must not apply and must be canceled as norms which cancel existing substantive guarantee of finding the objective truth and ensure the rights and freedoms of the individual, to narrow existing rights and freedoms of a person and contradict the existing Constitution of Ukraine, international legal acts and the principles and individual provisions of the norms of the Criminal Procedure Code.

We take attention to an interesting decision of the European Court of human rights (ECHR), in the case "Mirovni Inštitut v. Slovenia" from 13.03.2018, in which the ECHR established that the trial must guarantee the 
right to a public hearing within the meaning of article 6 , paragraph 1 , of the Convention, because such principle is a certain means of public control, one of the ways of asserting confidence in the court. Thus, the consideration of cases in simplified proceedings without calling the parties is contrary to the practice of the ECHR. According to the sentences handed down without a comprehensive examination of the evidence in court, it is possible, without a guaranteed right of the defendant to ask questions to witnesses who testify against him and without the participation of the defense in the study of other evidence, to be considered illegal. We can say also that according to article 17 of the Criminal Procedure Code of Ukraine: "Nobody is obliged to prove his innocence of committing a criminal offence and must be acquitted, if the prosecution does not prove the guilt of the person beyond a reasonable doubt".

There are certain objections to limiting the right to appeal a court verdict in the case of a plea agreement. Article 14 of the International Covenant "On civil and political rights" notes that "everyone, who is convicted of any crime has the right to hear his conviction and verdict by a higher court in accordance with the law".

In the case "Rostovtsev against Ukraine" (verdict from 25.07.2017), the court determines that "any restriction of the right of viewing contained in national legislation has to pursue a legitimate aim and not to violate the essence of this right by analogy with the right of access to court, which is enshrined in article 6, paragraph 1 of the Convention".

Wider implementation of the institutions of production on the basis of agreements into the investigative and judicial practice needs strengthening of safeguards to protect the rights and freedoms of the participants of the process; development and implementation better procedure of investigation and court consideration of the relevant cases taking into account the rule of law. The Institute of "effective repentance" and procedural forms of production on the basis of agreements need coordination. The plea agreement cannot be applied in criminal proceedings of Ukraine because of its contradiction to the norms of the Constitution of Ukraine. However, the procedural form of application of the Institute of effective repentance should be required. The agreement about the reconciliation of the suspect with the victim should be more widely applied. Taking into account the formation of the institution of criminal offenses, such agreements should become an unquestionable basis for the closing of the proceedings by the bodies of inquiry at the pre-trial stages of the process and by the court at any stage of the trial. Prospects for further study of the problem mean the development of a conceptual model of the Institute of active repentance and a separate Chapter of the Criminal Procedure Code of Ukraine which will be devoted to special forms of criminal proceedings. 
The norm "Exclusively a lawyer shall defend against criminal charges" (article 131-2) is fixed in the Constitution of Ukraine by the newly elected Parliament of Ukraine, under the slogans of abolishing the monopoly of lawyers to perform the functions of protection and legal assistance in 2019. On the one hand, the "advocate's monopoly" in criminal proceedings leaves unchanged and, on the other hand, the concept of "prosecution" in the law is insufficiently legally certain, because in the pre-trial stages of criminal proceedings against persons who are held to responsible, the act of notification of suspicion is done. So the question about subjects of protection from the ongoing public act of suspicious.

In the modern criminal process, a lawyer, as a representative of a human rights institution, which should do the function of legal assistance, can take part in criminal proceedings in three different statuses: 1) as a defender of a suspect, accused, convicted, acquitted, a person of whom compulsory medical or educational measures are envisaged and person who can be sent in extradition to a foreign state (article 45 Code of the criminal procedure of Ukraine), a person against whom the Institute of rehabilitation is applied in criminal proceedings; 2) as a representative of the victim (article 58 of the Code of criminal procedure of Ukraine) civil plaintiff, civil defendant; a third party (article 63 of the Code of criminal procedure of Ukraine), and as a the representation of persons, property of whom can be arrested (article 64-2 of the Code of criminal procedure of Ukraine); 3) as a legal assistant (consultant) of witness (article 66 of Code of criminal procedure of Ukraine) -legal assistance or in other words legal legal counsel.

None of the outlined competencies in Criminal procedure law has received a proper systemic legal definition yet. The law has not adequately regulated both the legal aid function as a whole and the protection function, which creates many problems in ensuring proper justice.

None of the outlined competencies in Criminal procedure law has received a proper systemic legal definition yet. The law has not adequately regulated both the legal aid function as a whole and the protection function, which creates many problems in ensuring proper justice.

These provisions create a certain competition of legal norms of national legislation and international legal acts, they are internally contradictory and controversial. First, the requirement of Art. 131-2 of the Constitution of Ukraine that "only a lawyer shall defend against criminal charges" does not mean the establishment of a monopoly of lawyers to perform the function of protection in criminal proceeding. So according to part 2 of article 42 of the Code of criminal procedure of Ukraine the guilty person is a person, the indictment about him is carried out to the court, according to the article 291 of Code of criminal procedure of Ukraine. Under the current Code of criminal 
procedure of Ukraine, protection from the act of suspicion is carried out at the pre-trial investigation, and protection from prosecution is possible only in the judicial stage of the process. Consequently, the provisions of the constitutional regulations that "exclusively a lawyer shall defend against criminal charges" do not exclude the protection of a suspect (a person, who has not accused yet) by another lawyer who is not an advocate. Secondly, this novella does not meet the requirements of art. 22 of the Constitution of Ukraine, concerning inadmissibility of restriction of the existing rights and freedoms at adoption of new laws, and also it contradicts the decision of the Constitutional Court of Ukraine, the basic international legal acts and case practice of ECHR.

The Constitutional Court of Ukraine in its decision on the 30-th of September, 2009 in the case of the constitutional appeal of the citizen Golovan Igor Vladimirovich concerning the official interpretation of the provisions of article 59 of the Constitution of Ukraine (the case of the right to legal aid), determined: 1. The provision of the first part of article 59 of the Constitution of Ukraine "everyone has the right to legal assistance" should be understood as a stateguaranteed opportunity for any person, regardless of the nature of his legal relations with state bodies, local governments, associations of citizens, legal entities and individuals to freely, without undue restrictions to receive assistance on legal issues in the scope and forms as he requires; 2. A person during interrogation as a witness in the bodies of inquiry, pre-trial investigation or giving explanations in legal relations with these and other state bodies has the right to legal (juridical) assistance from a person elected at his own request in the status of an advocate, this situation does not exclude the possibility of obtaining such assistance from another person, if the laws of Ukraine don't have restrictions.

Legal attorney can act as a lawyer or his assistant and other specialist in the field of law, in respect of which there are no statutory grounds for withdrawal from participation in the case.

Legal attorney has the right to:

1) be notified about the procedural status of the person who needs a legal assistance;

2) to get acquainted with the document about the call or other documents about presence of the person in the law enforcement Agency;

3) to provide to the persono to whom the legal aid is provided, consultation on legal questions in enough volume and forms, including confidentially within time, which does not infringe the rights of other persons;

4) to apply for a change in the procedural status of a person, if it does not comply with the requirements of the law;

5) to declare, in the presence of the bases provided by the law, challenge to the detective, the investigator, the prosecutor, the investigating judge, the judge; 
6) to apply for the application of security measures provided for by law to the person to whom legal assistance is provided;

7) to be present at carrying out investigative and other procedural actions which are carried out with participation of the person to whom the legal aid is rendered;

8) to explain to the person who is provided with legal assistance the right to refuse to testify and answer questions about himself, his family members and close relatives;

9) during carrying out procedural actions to put questions, to submit the remarks and objections concerning the order of carrying out actions which are brought in the Protocol;

10) get acquainted with the protocols of investigative (search) and other procedural actions performed with his participation and make written comments, clarifications and additions;

11)to apply technical means for fixing of results of procedural actions in which he is participant;

12) to submit evidence to the investigator, prosecutor, investigating judge, court;

13) to object to illegal actions of the detective, the investigator, the prosecutor, the investigating judge, the judge;

14) to provide legal assistance to a person in the preparation of written applications, complaints, petitions or claims, or with the consent of such person to make on her behalf written documents of a legal nature;

15)to file complaints against decisions, actions, inaction of the detective, the investigator, the prosecutor concerning interests of the person to whom the legal aid is rendered.

Legal attorney is obliged: to respect the rights and freedoms of human and citizen; not to impede establishment of the truth; to observe the principle of fair trial and under no circumstances to inform the court obviously incredible or unreliable information; not to disclose without the permission of the investigator, prosecutor, court, pre-trial investigation data and other information which has become known to him in connection with participation in criminal proceedings and which is the secrets protected by the law; to prevent the disclosure in any way of confidential information which has been entrusted to him or has become known in connection with the performance of his duties; to avoid committing acts which would harm the interests of the person assisted or the rights and freedoms of others."

\section{CONCLUSIONS}

In the implementation of constitutional and legislative reform, it is important to strictly adhere to the principles of the rule of law, legal certainty, 
and in the legal positions of the European Court of human rights, the principle of proportionality. Requires the development of a conceptual model of the new Constitution of Ukraine and the procedure for its adoption by popular referendum. The implementation of this order the adoption of the Basic Law of the State.

\section{SUMMARY}

The adoption of the Constitution of the State through the national referendum is a legitimate and effective way to harmonize the legislative power in General and in particular. While the Basic Law of the State, gets its jurisdiction directly from the people and becomes a higher power, and the authorities are no longer able to change it on your own. The authorities should not be "Supreme", and serve as the law and ensure the rule of law, the person and the citizen.

\section{REFERENCES}

1. Головатий С. Верховенство права. У $3-x$ книгах. Книга 2. Верховенство права: від доктрини до прецеденту. Київ: Видавництво “Фенікс", 2006. 1286 с.

2. Коваль А.А. Забезпечення прав людини при провадженні негласних слідчих (розшукових) дій : монографія. Миколаїв: Вид-во ЧНУ ім. Петра Могили, 2019. 264 с.

3. Козюбра М. Судова правотворчість: аномалія чи іманентна властивість правосуддя. Право України. 2016. № 10. С. 38-48.

4. Колодій А.М., Олійник А.Ю. Права, свободи та обов'язки людини і громадянина в Україні: підруч. Київ: Правова єдність, 2008. 350 с.

5. Коломоєць Т.О., Колпаков В.К. Науково-практичний коментар Закону України “Про запобігання корупиії”. Київ: Видавничий дім “Гельветика". 2019. 588 с.

6. Корнієнко М.В., Тертишник В.М. Принципи права в розв'язанні юридичних колізій. Міжнародний науковий журнал "Верховенство права". 2017. № 2. С. 10-16.

7. Костенко О.М. Концепџія прав людини: сучасний стан $i$ перспективи розвитку. Бюлетень Міністерства юстиції України. 2011. № 11 C. $5-11$

8. Мироненко П.В. Форма правління: політичні трансформації на зломі століть: монографія. К.: Академія, 2014. 220 с.

9. Михайленко В.В. Співвідношення засад верховенства права $i$ законності у кримінальному процесу України. Прикарпатський юридичний вісник. Івано-Франківськ, 2017. № 6 (21). Том 2. С. 158-163. 
10. Наливайко Л.Р. Захист прав $i$ свобод в світлі положень Конституції Украӥни та конвенції про захист прав людини і основних свобод. Держава і право. Юридичні і політичні науки. 2003. Спецвипуск. C. 343-345.

11. Оніщенко Н.М. Принциип верховенства права та верховенства закону: взаємовиключення чи взаємозумовленість? Проблеми правознавства та правоохоронної діяльності. № 3. 2010. С. 3-7.

12. Орловська Н.А. Справедливість і верховенство права: актуальні питання кримінально-правової інтерпретації. Науковий вісник Херсонського державного університету. Сер. : Юридичні науки. 2014. Вип. 6-1. Т. 3. С. 158-163.

13. Петришин О. Верховенство права в системі правового регулювання суспільних відносин. Право України. 2010. № 3. С. 27-29.

14. Подорожна Т.С. Правовий порядок: теоретико-методологічні засади конституціоналізаиії: монографія. Київ: Юрінком Інтер, 2016 $536 \mathrm{c}$

15.Принции верховенства права: проблеми теорії та практики: Монографія: У 2-х кн. / За заг. ред. Ю.С. Шемшученка. К.: Юридична думка, 2008. Кн. 1. Верховенство права як принцип правової системи: проблеми теорії. 344 с.

16. Сачко О.В. Кониептуальна модель юридичного визначення принщипу верховенства права. Актуальні проблеми вітчизняної юриспруденції. 2018. № 6. Т. 1. С. 166-170.

17. Ставнійчук М. Окремі проблеми новітнього конституційного прочесу у світлі висновків Європейської комісіі "За демократію через право” (Венеціанська комісія). Право України. 2012. № 8. С. 146-153.

18. Тертишник В.M. Вid тоталітарності до правовладдя: доктринальні аспекти державотворення. Право.иа. 2017. № 2. С. 5-11.

19. Тертишник В.М. Правнича допомога та захист у кримінальному процесі: Підручник / За заг. ред. д.ю.Н., академіка НАН України Ю.С. Шемшученко. Київ: Алерта, 2018. 480 с.

20. Тертишник В.М., Корнієнко М.В. White-Collar Crime в "модних піджаках”. Європейські перспективи. 2018. № 3. С. 55-54.

21. Фулей T.I. Застосування практики Європейського суду з прав людини при здійсненні правосуддя: Науково-методичний посібник для суддів. 2-ге вид. випр., допов. К., 2015. 208 с.

22. Хавронюк М.I. Коментар законодавства Украӥни про права та свободи людини і громадянина. Київ: Парламент. 1999. 544 с.

23. Цибуляк-Кустевич А.С. Сучасні виклики та актуальні проблеми судової реформи в Украӥні. Право України. 2018. № 11. С. 214-230. 
24. Ченцов В.В., Тертишник В.М. Реабілітація жертв незаконних кримінальних переслідувань, політичних репресій та зловживань владою. Підручник для слухачів магістратури. Київ: Алерта, 2016. 324 с.

25. Шилінгов В.С. Верховенство права - основоположний принцип правової системи демократичного суспільства. Часопис київського університету права. 2009/2. URL: http: www.kul.kiev.ua/images/chasopus.

26. Щербанюк О.В. Народна правотворча ініціатива як перспективний інститут прямої демократії в Украӥні. Порівняльноаналітичне право. 2013. № 3-2. С. 97-100.

Information about the authors: Tertyshnyk V. M.,

Doctor of Law, Professor, University of Customs and Finance 2/4, Volodymyra Vernadskoho str., Dnipro, 49000, Ukraine Yarmysh O. N., Doctor of Law, Professor, Corresponding Member of the National Academy of Legal Sciences of Ukraine, President of the International Association of Historians of Law, Senior Research Associate of the Legislation Institute of the Verkhovna Rada of Ukraine 